\title{
Atlantis
}

Critical Studies in Gender, Culture \& Social Justice

Études critiques sur le genre, la culture, et la justice

\section{Transversal and Postmodern Feminist Praxis in Everyday Politics}

\section{Jenny Roth et Lori Chambers}

Volume 40, numéro 1, fall 2019

URI : https://id.erudit.org/iderudit/1066417ar

DOI : https://doi.org/10.7202/1066417ar

Aller au sommaire du numéro

Éditeur(s)

Mount Saint Vincent University

ISSN

1715-0698 (numérique)

Découvrir la revue

Citer cet article

Roth, J. \& Chambers, L. (2019). Transversal and Postmodern Feminist Praxis in Everyday Politics. Atlantis, 40(1), 1-17. https://doi.org/10.7202/1066417ar
Résumé de l'article

Feminist praxis is usually a conscious, reflexive process of moving from theory to application in order to create transformation. We want to expand the scope of feminist praxis, however, to include moments in which feminist theory explains political transformations that may not be deliberate but that result in a feminist outcome: the pursuit of gender equality through personal and political transformation. This paper uses a dataset of online comments generated after the Supreme Court of Canada decision in R. v. N.S. as a case study, and it sits in conversation with postmodern and transversal feminist theorists, particularly the recent work of Patricia Hill Collins (2017) that builds on Nira Yuval-Davis (1997) and others, to argue that political action is most effective when transversal practice is layered onto intersectional politics and that, despite Hill Collins' concern that political practice has yet to move to effective transversalism $(2017,1471)$, transversal feminist praxis can be found in examples of everyday politics which offer hope for social transformation.
Ce document est protégé par la loi sur le droit d'auteur. L'utilisation des services d’Érudit (y compris la reproduction) est assujettie à sa politique d'utilisation que vous pouvez consulter en ligne.

https://apropos.erudit.org/fr/usagers/politique-dutilisation/ 


\section{Transversal and Postmodern Feminist Praxis in Everyday Politics}

Jenny Roth is a Professor in Women's Studies at Lakehead University. She publishes in discourse analysis, law, literature, and cyber-/technofeminism. Her current work focuses on Bram Stoker's Dracula, gender, technology, and artificial intelligence. Jenny teaches undergraduate and graduate courses in feminist theory, science fiction, horror films, law and literature, and gender and technology.

Lori Chambers is a Professor in Women's Studies at Lakehead University. She publishes on a range of legal issues related to equity and diversity. Her current work is on domestic terrorism and the response of police and courts. Lori teaches women's legal history, current legal issues, queer theory, and graduate courses in feminist theory and activism.

\begin{abstract}
Feminist praxis is usually a conscious, reflexive process of moving from theory to application in order to create transformation. We want to expand the scope of feminist praxis, however, to include moments in which feminist theory explains political transformations that may not be deliberate but that result in a feminist outcome: the pursuit of gender equality through personal and political transformation. This paper uses a dataset of online comments generated after the Supreme Court of Canada decision in $R . v . N . S$. as a case study, and it sits in conversation with postmodern and transversal feminist theorists, particularly the recent work of Patricia Hill Collins (2017) that builds on Nira Yuval-Davis (1997) and others, to argue that political action is most effective when transversal practice is layered onto intersectional politics and that, despite Hill Collins' concern that political practice has yet to move to effective transversalism $(2017,1471)$, transversal feminist praxis can be found in examples of everyday politics which offer hope for social transformation.
\end{abstract}

Keywords: transversal feminism, postmodern feminism, praxis 


\section{Introduction: Praxis and Postmodern Transversal Politics}

Feminist praxis is usually a conscious, reflexive, process of moving from theory to application in order to create transformations (see, for example, Allen 2000; Archer Mann 2012; Cho, Crenshaw, and McCall 2013; De Reus, Few, and Balter Blume 2005; Evans 2016; Hesse-Biber 2012; Naples 2013; and Sharp et al. 2017). We want to expand the scope of feminist praxis, however, to include moments in which feminist theory explains political transformations that may not be deliberate, but that result in a feminist outcome: the pursuit of gender equality through personal and political transformation. Finding these moments is important at a time when, politically, it seems that anti-equality movements are gaining ground. This paper uses a dataset of online comments generated after the Supreme Court of Canada decision in R. v. N.S. as a case study. It sits in conversation with postmodern and transversal feminist theorists, particularly the recent work of Patricia Hill Collins (2017) that builds upon the previous work of Nira Yuval-Davis (1997) and others, to argue that political action is most effective when transversal practice is layered onto intersectional politics. Further, we argue that despite Hill Collins' concern that political practice has yet to move to effective transversalism $(2017,1471)$, transversal feminist praxis can be found in examples of everyday politics which offer hope for social transformation.

Postmodern and transversal feminist theories explain people's political transformations. In the current antiintellectual political climate, we want to illustrate how layering theory onto everyday political transformations reveals that transformative praxis can be found around us, even when it is not consciously deliberate. That is, transversal and postmodern feminist theories, which challenge the false binaries that divide people into oppositional political positions, do not just explain the roots of gender inequality but also illuminate the pathways to politics that can be identified as feminist in their outcomes (see, for example, Kolmar and Bartkowski 2010, 2-6; and Lorber 2012).
Postmodern feminist praxis challenges rigid identity boundaries between "self" and "other," nationally and individually, and produces points of connection across identity groups. It "undermines foundational categories by insisting that bodies, identities, and statuses are contingent-time-bound, situational, and culturally shaped" (Lorber 2012, 285). Feminist postmodern theorists argue that the sex-gender binary is a false construct produced by cultural beliefs and practices at particular moments in time and place. The intersectional postmodern approach extends the binary beyond sex-gender to multiple categories, allowing analysis along different valences to undermine fixed binaries like "Black/White," "gay/straight," "abled/disabled," "young/old," etc.

Transversal feminist praxis developed during the same period as postmodern feminism in the late twentieth century and emerged from coalition-building groups where women worked "not just with different others but with ... enemies" (Bastian 2006, 1039; also see Cockburn 1998; Yuval-Davis 1994, 179-197; and Yuval-Davis 1997). Transversal feminism recognizes that "politics based on a homogenous notion of identity is spectacularly unable to deal with the problem of working toward peace" (Bastian 2006, 1039). Instead, the theory argues that "by questioning how one understands one's sense of identity, by reducing defensive reactions and attempting to broaden one's point of view, less aggressive responses to conflict can become more than a naïve hope" (Bastian 2006, 1039). The processes of opening up identity to engage fluidly with similarity in others is embedded in postmodern feminism, and transversal processes based on shifting one's identity position diffused many arguments in our dataset, in part because transversal praxis allowed people to "keep one's own perspective on things while empathizing and respecting others" (Yuval-Davis 1994, 193).

\section{Methods}

We explore possibilities for transformation using the online comments that appeared after the Supreme Court of Canada's decision on women's right to veil 
in the courtroom in R.v.N.S, as a case study. The Canadian Supreme Court case R. v. N.S. considered the right of a Muslim woman to wear a niqab while testifying as a victim in a sexual assault trial. The court determined the case involved a conflict between the religious rights of N.S., protected under s. 2 of the Canadian Charter of Human Rights and Freedoms (Charter), and the s. 7 Charter rights of the accused to a full and fair defense, which lead to an ambiguous decision: that Muslim women could veil in court so long as the presiding judge did not see that as an impediment to the trial process. The very ambiguity of the decision prompted legal commentary. Critics have asserted that the decision will not permit women to veil in court, as most judges will deem that the inability to see the face, and therefore to assess the credibility of the witness, constitutes an impediment to a fair trial and a full defence (Chambers and Roth 2014, 382).

The case divided the court and sparked intense public debate. Speaking for the majority in R. v. N.S., Chief Justice Beverley McLachlin admitted that the issue of "effective cross-examination and accurate assessment of a witness's credibility" was hotly disputed. She asserted that "provisions of the Criminal Code ... and judicial pronouncements" presume that the "ability to see a witness's face is an important feature of a fair trial" and that "this common law assumption cannot be disregarded lightly" (R. v. N.S., [2012], 3 SCR 726, para 21). Although she noted that "if ... women are required to remove the niqab while testifying against their sincere religious belief they will be reluctant to report offences and pursue their prosecution" (R. v. N.S., [2012], 3 SCR 726, para 37), she also asserted that the interests of the accused and "safeguarding the repute of the administration of justice" were more compelling in this case since "no less is at stake than an individual's liberty" ( $R$. v. N.S., [2012], 3 SCR 726, para 38). Concurring, Canadian Supreme Court Justices LeBel and Rothstein asked whether wearing niqab in any trial was compatible "with the constitutional values of openness and religious neutrality in contemporary democratic, but diverse, Canada" (R. v. N.S., [2012], 3 SCR 726, para $60)$.
We found Islamophobia and Orientalist sexist discourse at the heart of the Majority's decision and we have argued that the decision ultimately legitimized racist and sexist stereotypes that deny Muslim women's full participation in Canadian society (Chambers and Roth 2014, 386-389). Only Justice Abella, in dissent, considered the structural discrimination the anonymized N.S. faced as a Muslim woman, and asserted that "the harm to a complainant of requiring her to remove her niqab while testifying will generally outweigh any harm to trial fairness" (R. v. N.S., [2012], 3 SCR 726, para 86). The majority found that a judge would have to make a decision in each individual case as to whether or not a niqab would be allowed, and provided a framework for such decisions (R. v. N.S., [2012], 3 SCR 726, para 38). This ambiguity led to a large amount of online debate. For example, in response to statements that the Supreme Court should have prohibited the niqab in all cases to protect Canada from "foreign ways," one commenter interjected: "Breaking news just now ... : Supreme Court of Canada KILLS Canada" (ArtisteNow 2012). Another less acerbic writer added: "This is a tough one, with sound Charter arguments on both sides. It could go either way, and-whichever way they rule-they'll be wrong. // Glad I'm only a lowly HuffPost commenter today, and not a Supreme Court Justice" (Anonymous 2012).

In online comments, people debated the decision and its future application from their own perspectives on human rights and the law, which provided a breadth and depth of data we could draw on to illustrate how postmodern and transversal feminist theory can be applied to everyday encounters and personal transformation. We examined discussions on three mainstream Canadian media sites, Maclean's Magazine, Huffington Post, and the National Post, where the most substantive and responsive commentary occurred. These sites provided us with over 200 discussion and comment entries from which to draw examples of praxis in everyday interactions. Transversal and postmodern feminism explain how discussants moved from positions of political opposition to build peace, understanding, and bridges. Although 
the discussants may or may not have deliberately used feminist approaches in their attempts to realign oppressive attitudes-given the nature of online discussion, it is impossible to know what people do not divulge - it is clear that transversal and postmodern feminist praxis, deliberately or unknowingly brought into being, were at the heart of peace-building praxis.

\section{The Political Context of Personal Posi- tions: Islamophobia in the Economic North}

The oppressive binary of us/them identity politics appeared in $R . v$. N.S., in both the court's decision and the online debates; a brief contextualization of the political context of the case is therefore useful. It seems unnecessary to write that Muslims in nonMuslim countries have faced increasing surveillance and Islamophobia since $9 / 11$. We have no interest in examining how Islamophobia is perpetuated online: our focus is on feminist praxis in everyday encounters. We certainly join other cultural critics to denounce Islamophobia as oppressive (see for example: Arat-Koc 2005; Awan 2016; Cammaerts 2009; Carr 2016; Haque 2010; Kahn and Kellner 2004, 89, 9394; Love 2017, 83-116; and Razack 2008, 173) and we recognize that the intersection of sexism and Islamophobia produces particular outcomes. For example, media reports from the United Kingdom suggest Islamophobic violence is often gendered, with women who veil in any way (hijab, niqab, or burqa) bearing the brunt of verbal and physical attacks (Vidal 2014; see also Perry 2014). Many scholars and activists have documented how veils have become symbols of both the threat of fundamentalist extremism and, paradoxically, women's vulnerability to abuse and subordination under purdah patriarchies (see for example, McDonough 2003, 126-130; and Simpson, James, and Mack 2011).

In their brief to the Court in R.v.N.S., for example, the Canadian Council on American-Islamic Relations wrote: "[I]n popular discourse they [niqabwearing women] are either vilified as fanatics who refuse to integrate, or infantilized as victims who are prevented from seeing their own oppression" (qtd. in Chambers and Roth 2014, 386). LEAF, the Women's Legal Education and Action Fund in Canada, similarly argued as intervenors in $R . v$. N.S.:

Although the small number of women who wear the niqab in Canada are not a new phenomenon, various national and international events ... have changed the political climate in which they are viewed.... The niqab is perceived as belonging to a culture/religion/valuesystem which is stereotyped as extremist and inimical to Western cultures and values. In this context, the niqab has become emblematic of an irreconcilable "clash of cultures." (2013)

At the heart of "clashes of cultures" are the national and individual identities people use to situate themselves, their nation, and their perceived national/identity values in relation to others. These identity-based politics have proven difficult to overcome, as Hill Collins points out $(2017,1471)$, but postmodern and transversal theories show how the barriers created by entrenched identity politics can be transformed through praxis into feminist outcomes.

\section{Postmodern Feminism: Identity Permeabil- ity and Feminist Praxis}

As noted above, postmodernism challenges the traditional modern narratives about contained and carefully bounded identity-subjects. In the debates produced by $R . v$. N.S., the primary binaries invoked were cultural: West/Non-West, Non-Muslim/Muslim, Canadian/Foreigner, Liberated/Oppressed. That the debates engendered by R. $v$. N.S. centred around the question of controlling women's bodies-what women are or are not allowed to wear-makes these debates gendered. Like Homi Bhabha's "third space" (1994), online comments sections are liminal because they require active identity production. They usually lack the visual and aural signifiers that are often used to produce identity, thus revealing that identity positions, including gender, are performative: they must be named in an online space and are not inherent or intrinsic (Lorber 2012, 284). In our dataset, there is 
ample textual evidence of how people construct themselves in relation to other nationalities or communities, and in relation to those whom they perceive to be, and define as, outsiders. As postmodern feminist Judith Butler has argued, "bodies" are "a kind of materialization governed by regulatory norms"; she probes how the "materialization of the norm in body formation produce[s] a domain of abjected bodies" that are perceived to be "less-than" those who are "normative" (Butler 1993, 15-16). Critic Shahnaz Khan has further argued that liminal third spaces are places where contradictions in identity construction can eschew colonial authority to produce postmodern, transnational subjects who are more likely to recognize the shared foreignness of identity positions (1998). At minimum, the online comments sections in our dataset were places where multiple "authentic" Canadian identities existed simultaneously, thus disrupting any claims to one authentic cultural or national identity through the very existence of pluralism.

This pluralism allowed the ideology of Canadian multiculturalism to support a more fluid postmodern identity. If not in practice, at least ideologically, multicultural Canada has the possibility to be plural, porous, and encompassing. Since 1971, Canada has been formally multicultural and multiculturalism was enshrined legally in the Charter of Human Rights and Freedoms in 1982. In one definition, Canadian multiculturalism encourages and supports cultural pluralism, diversity, and equality for all. In practice, as many critics have noted, it has been a political tool aimed at social control and the containment of interethnic violence (see, for example, Allahar 1998, 340342) and is often used to silence cultural dissent by obfuscating racist and xenophobic structures. Unfortunately, therefore, in practice it usually creates a "discourse of diversity" wherein those who are "multicultural ... are merely ... tolerated, but not accepted as 'real' citizens" (James 2005, 19-20; see also Bannerji 2000). Thus, critics argue that multiculturalism is an effective Eurocentric tool because it defines people as being "multicultural" in relation to an invisible core group of "real" citizens who are, in
Canada, normalized to be of white British and French settler descent (Jiwani 2006, 189; see also Simpson, James, and Mack 2011).

The multiculturalism invoked at the grassroots level in our dataset, however, appealed to the ideal of Canadian multiculturalism: a society that seeks and respects cultural diversity, that works against racism and xenophobia, and that espouses the benefits of a diverse community. As Anton Allahar writes, although multiculturalism does little to address structural racism, "[w]here it works ... multiculturalism is a very effective form of resistance to racism" (1998, 338-339). For Canada's national identity construction, multiculturalism is the "Canadian Way" (Driedger 1989, 238) and is often used to differentiate Canada from the United States (Allahar 1998, 340). When this form of multiculturalism is invoked, it appeals to a Canadian identity that is not culturally fixed, except insofar as it is culturally proliferous. The challenges that multiculturalism has made to dominant systems of authority and its connections to the postmodern undermining of grand narratives have been articulated in literary theory (see for example: Caton 1997; Kamboureli 2007; Mohanty 1997; and Poster 2009; and Yanyu 2004, among others), which argues that a cultural identity of multiply-located cultures is democratisation that reflects the fluidity of postmodern identities. This is not to say that identifying permeability is the same as easily overcoming racist structures. As Sarah Ahmed (2000) has warned, permeability is easily "achievable for those whose experiences of race are not lived as a barrier to entering of even inhabiting certain spaces. For those who are marginalised by the racial norm [of whiteness], racial identity means living with constraint and fixity" (58). It is the case, however, that multiculturalism was often invoked by commenters who identified as Muslim and/or racialized in a call to the permeability of what it is to be Canadian.

Samira Kanji and Azeezah Kanji, for example, noted in their National Post article that the Supreme Court decision "provides a timely opportunity for some much-needed reflection on the way we talk about the 
niqab in Canada." They call for "multicultural respect" and cite s. 27 of the Charter which states that rights must be "interpreted in a manner consistent with the preservation and enhancement of the multicultural heritage" of Canada (2012). Many others argued similarly. In a debate that took place on Huffington Post (HuffPost), Nellie_Niqabi wrote: "I demand respect because that's what I have been promised when I came here. ... And by respect, I mean having the freedom to dress the way I want, and be myself" (2012a). Overt Enigma asked of readers: "What do you deem more important, protecting the charter of rights and freedoms and working with the communities to find a ... solution, or to embrace paranoia ... and portray this one ruling as the 'end of times"' (2012b). Brian 25 argued the benefits of a culturally diverse Canada in his comment back to right-wing journalist Barbara Kay's article in the National Post: "We are a multicultural country where all cultures and traditions are equally honored and respected. ... You are stuck in the past where Canadian meant western or European. It doesn't anymore. Today it means all cultures and traditions" (2012). Cindy Zheng, commenting on Mike Blanchfield's Maclean's article, similarly wrote: "I think the court was wise to avoid a simple rule that is a one-size-fits-all approach. Since we live in a multi-cultural society, we must be prepared to accommodate others, whether that be in the courtroom or at the office" (2012). And, in response to novabird's statement that Muslim women who "do not wish to respect Canadian laws ... can return to their countries of origin" (2012), Cindy V. asked, "Where are they supposed to go if they were born in Canada?" (2012). These commenters draw on the fluid, postmodern national identity of multiculturalism to argue for personal and political transformation.

In doing so, they eschewed a rigid, single definition of "Canadian" in favour of cultural pluralism, and thus embodied a liminal and postmodern worldview where different cultural practices sit comfortably together. In such everyday political views, veiling was often described as a choice made in a free and democratic multicultural country. For example, Mike $\mathrm{T}$., in response to some commenters' arguments that allowing veiled women in court would change the very nature of Canada, asked: "Where does it say 'we' have to change? No one is forcing anyone to change. Where does it say that Canadian women HAVE to wear the niqab while testifying. It's a choice" (2012b). Similarly, Nicholas $\mathrm{T}$ adopted a comfortable postmodern position in relation to national identity when he wrote:

If you bothered to ask the women themselves, you might find that they ... wear the niqab by choice. If so, to tell them they can't wear one is to take away their freedom to decide, and that would be an act of oppression, would it not? How is it any of your business to push your interpretation on her and brand it as the accepted 'Canadian' one? (2012)

In support of Nicholas $\mathrm{T}$, and in answer to arguments that women who veil are oppressed, Nellie_Niqabi responded that she feels "totally liberated," and argued that veiling allows women to be "judged" for their minds, "not the way we look" (2013).

For those who employed an everyday personal politics of postmodern multiculturalism, the gendered aspect of the case was important. Some commenters made arguments for N.S.'s rights as a woman who must unveil in front of her alleged assailants after years of sexual assault. Liz_Wilson_2 wondered "what is more important in this situation, to prosecute the men that have assaulted her-giving justice and access to legal recourse for Islamic women in Canada or to force her to appear unveiled?" (2012a). Mike T. argued that the context of the rape trial is important: "To force her to figuratively disrobe in front of the alleged rapists is really disturbing" (2012a). Mike T.'s use of cultural relativism (whether conscious or not) revealed the effects of postmodernism at work: disrobing was understood differently on the basis of cultural differences. When novabird accused Mike T. of hyperbolizing because " $[\mathrm{m}]$ any thousands of North American women face their accusers in court without covering their faces" (2012), they missed Mike T's point about postmodern cultural pluralism, which he 
reiterated: the women who appear unveiled in court, he responded, have "been brought up in an atmosphere where showing their face is a normal, everyday happening. This woman wasn't. It's just a basic human kindness to a traumatized woman" (2012c).

Other responses to novabird's position that women must unveil in court also reveal the strength of postmodern multiculturalism in relation to the law. RK2880 wrote, "Read the decision-according to Canadian law, wearing a niqab IS acceptable. Women who wear it while testifying are respecting Canadian laws" (2012). Overt Enigma argued: "Forcing any group of people to conform to your understanding and system of values is contrary to multiculturalism, tolerance and the values upon which Canada was founded" (2012a). Although Torontosaurous denounced veiling in general, he also wrote, "[f]rom a legal stand point [sic],as [sic] long as the judge rules that this is indeed the woman that is the accuser,and [sic] not an imposter,and [sic] those charged agree that the woman is who she says she is,I [sic] see no problem" (2012a). All of these commenters' arguments illustrate a strong, if unconscious, commitment to postmodernity: in order for them to make claims that Canadians occupy multiple, relative, cultures, they must adopt a comfortable postmodern position in which national identity is permeable and diverse.

That they do so in order to defend a woman's right to dress as she chooses illustrates that postmodern feminist praxis can be found in unlikely places. It is not apparent that any of the commenters were consciously working from a position of feminist politics, which is our point: there are hopeful signs of cultural change in this wider appearance of what is very likely unconscious postmodern feminist praxis. While some commenters did not immediately espouse a postmodern view and began their discussion with a fixed, bounded definition of what it is to be "Canadian," when they changed their view, their changes can be explained by transversal feminist praxis: the process that allows the movement from a fixed to a permeable identity and which is closely connected to the postmodern aims of complicating identity politics. As $\mathrm{Pa}$ - tricia Hill Collins argues, "analysis is important, yet action also matters," and "transversal politics [is] a form of political engagement that ha[s] important implications for understanding organized political resistance" $(2017,1467)$.

\section{Postmodern Theory to Transversal Praxis: Rooting and Shifting}

In our study, transformations in people's personal political views often occurred when discussants made empathetic connections between Islamophobic oppression and their own experiences, leading them to articulate similarly-held Outsider positions. This moved them from a fixed identity position to postmodern permeability, and on to transversal praxis. Nira Yuval-Davis, arguably the most prolific writer on transversal praxis, explains that transversal politics "developed as an alternative to the assimilationist 'universalistic' politics of the Left, on the one hand, and to identity politics, on the other hand" (2006, 281). Transversal feminism is "dialogical standpoint epistemology ... a recognition that from each positioning the world is seen differently, and thus any knowledge based on just one positioning is 'unfinished" (2006, 281; see also Harding 1991; and Stoetzler and Yuval-Davis 2002). Like postmodernism, transversal feminism recognizes that identities are complex:

People who identify themselves as belonging to the same collectivity or social category can actually be positioned very differently in relation to a whole range of social locations (e.g., class, gender, ability, sexuality, stage in life cycle). At the same time, people with similar positionings and/or identities can have very different social and political values. (Yuval-Davis 2006, 281; see also Yuval-Davis 1994, 1997, and YuvalDavis and Stoetzler 2002)

Recently, Patricia Hill Collins reflected on her 1998 article "The Tie that Binds," where she argued that combating race-based violence required "a more sophisticated transversal politics that took intersecting power relations into account," because "intersectional 
analyses, on their own, are unlikely to yield ... effective political solutions to violence" (2017, 1460-61). She noted that "action matters ... transversal politics [is] a form of political engagement that [has] important implications for understanding organized political resistance" (2017, 1467). Drawing on the work of Yuval-Davis, Hill Collins examines coalition-building within and outside of historically constructed group identities $(2017,1469-72)$ and argues that the Black Lives Matter movement shows how the "flexible solidarity honed through Black women's politics" can work with "transversal politics as a framework for coalitions among groups that inform anti-violence initiatives" $(2017,1471)$.

Coalition building is important: as Yuval-Davis pointed out, the result of mid-twentieth century hegemonic constructions of feminist politics was "identity politics." From an intersectional perspective, the constructions of anti-racist politics in the civil rights movement shared the same outcomes (see also Moghadam 1994). Yuval-Davis explains that

in such politics all the members of the oppressed social category are constructed as homogenous; all dimensions of social location are reduced into the primary one. Thus there is no differentiation in this approach between categorical locations, social identities, and political values ... identity politics conflates individual and collective identities, therefore assuming that any member of any social category or identity can speak for all the other members of that category ... "as a woman," "as a black," and so forth. (2006, 277)

She argues that early corrections of the gender hegemony in the mainstream feminist movement only continued to reify essentialist constructions of identity by simply fragmenting and multiplying descriptors: i.e. "as a disabled woman," "as a lesbian Asian," etc., "rather than a rejection of that model of identity politics itself" (2006, 278, 281). Integrative feminist analysis, formed contemporaneously with poststructuralist and postmodern feminist theories, tries to address the fragmentation produced by identity politics' essentialism (Yuval-Davis 2006, 278).
Transversal feminism has been used effectively for coalition-building between different women's groups (see Yuval-Davis 1994, 2002) because in taking a dialogical standpoint people no longer "speak for" their constituencies in an essentializing way but are rather messengers engaged in political dialogue, bringing with them "the reflective knowledge of their own positioning and identity. This is the rooting" (YuvalDavis 2006, 282). Rooting, the first stage in transversal feminist practice, is when participants do the deep work of thinking about their own identity positions-how they define themselves - and recognize that they cannot speak in an essentializing way "as a..." due to the complexity of intersectionality; rather, they bring partial knowledge from their own complex positions. The second stage in transversal feminist practice is shifting: when participants "put themselves in the situation of those with whom they are in dialogue and who are different from them" (Yuval-Davis 2006, 282). Transversal feminism assumes that people are capable of empathy and that the shifting process involves a careful examination of the "compatible values" that "cut across differences in positionings and identities" (2006, 282). As Yuval-Davis points out, "[ $t]$ he struggle against oppression and discrimination might (and mostly does) have a specific categorical focus, but it is never confined just to that category" (2006, 282). For example, when Hill Collins writes about the transversal roots of the success of the Black Lives Matter movement $(2017,1471)$ and argues for the need to move towards transversal political action in more meaningful ways, she describes how multiple groups came to align themselves with the Black Lives Matter movement.

Hill Collins argues that transversal politics is the necessary but "as yet unrealized future" of political activism $(2017,1471)$. The challenge, in terms of praxis, is likely that, on the one hand, decades of feminist and other critical evidence has shown that identities like sex, race, and class, are social constructions and therefore "false:" there is no natural, biologically-determined identity to embody. Further, experts have shown that these identities have been, and are, imposed through relations of power and domination 
(the extensive and "scientific" Imperial classification and invention of different races in the nineteenth century is an example, see for example Hill Collins 1998; hooks 1989; Lorde 1984; and McClintock 1995). For this reason, postmodern, transversal, poststructuralist, and intersectional feminist theorists argue that equality can be pursued by showing how the false hegemonic binaries of male/female, white/black, straight/gay, etc. crumble under scrutiny.

However, on the other hand, the constructed "falseness" of hegemonic identities exists alongside the material lived effects of those constructions so that decades of evidence in feminist and other critical disciplines also shows that statements like "women are the majority of victims of spousal abuse" and "Indigenous women in Canada are more likely to suffer sexual violence than non-Indigenous women" are not only valid but, in a society of inequalities created by false binaries, they are also politically expedient and necessary (see, for example, Butler 1993, 1-23). Society is not yet in a position where it is simply a matter of recognizing the falseness of either/or identity construction and its historical connections to power relations and domination to dissolve inequality. Identities remain important and this, perhaps, is why Hill Collins (2017) writes that the future possibilities provided by transversal feminism are as yet unmet.

Similarly, Yuval-Davis has pointed out that transversal feminist practice is difficult because both the rooting and shifting stages need to remain fluid, not "straightforward or fixed" (2006, 284). The purpose of rooting in one's identity is "not to imagine oneself just in relation to the social category of the Other but also in other ways through which different kinds of relationships with the partners in the transversal dialogue may be developed" (2006, 284). Hill Collins notes that "the process of shifting must maintain the multiplicity of perspectives both within a group and across groups. This is the difficult challenge, one that recognizes that some coalitions may not be possible" (2017, 1470). Despite the difficulties, however, many moments of transformation in online commenters' political views illustrate transversal feminist praxis in process. Both Yuval-Davis and Hill Collins argue that intersectionality provides multiple identity meeting points (roots) from which people can connect and shift. For many in Canada, one shared identity point is that of settler.

When commenter rattler wrote that a "creeping acceptance of cultures alien to Canada has reached a saturation point. ... The [immigration] 'welcome' mat is no longer at my door" (2012), for example, Yasmin responded: "I'm sure the First People would agree with you, and would be more than happy to help you pack your goods so that you can move back to Europe. Alien culture indeed" (2012). Yasmin invokes rattler's shared otherness with women who veil as a non-Indigenous settler, suggesting that rattler's perceived right to be in Canada should extend to Muslim Canadians who are, similarly, settlers on someone else's lands. Julia Kristeva's now-germinal work on the construction of foreignness is helpful here: Kristeva (1991) argued that "the foreigner" is formally one who holds a different nationality. In Canada, transnational politics and identity formations produce multiple "foreign" identities (e.g., African American, Italian-Canadian). This holds true even in the discursive construction of First Peoples, who are often represented as "ethnicized" in relation to white settlers to support the myth of white indigeneity and entitlement to the land (see for example Bohaker and Iacovetta 2009). Kristeva argued that postmodern identities allow for multiple points of recognition because we are no longer "fixed" in terms of the relationships between nation-state and self, thus illustrating the link between postmodernism and transversal praxis: when people recognize shared foreignness, outsiders cease to exist because all become outsiders $(1991,96)$.

Sara Ahmed's (2000) work on "the stranger" similarly notes that the stranger is both "familiar and strange" because of their "proximity." The stranger's very positioning in a shared space is what produces people as strangers in the first place: "[T]he strangers come to be seen as figures (with linguistic and bodily integrity) when they have entered the spaces we call 'home" 
(49). In this sense, all non-Indigenous Canadians have, at one time or another, occupied the position of stranger who becomes incorporated into the home lands (50). In our study, the shared identity location of settler-Outsider was often invoked by commenters to try to create moments of connection across identity locations, a move that reflects transversal praxis' deliberate rooting and shifting.

For example, Nellie_Niqabi shared why she veils and her unhappiness with a society that treats her as a foreigner. Her language suggested she was upset when she wrote that "these brainwashed masses are trying to teach us what our religious requirements are. They are trying to 'liberate' us by passing us snide comments in public and and [sic] trying to tug our veils off. ... The impression that all women who wear the veil are oppressed is completely stereotype" (2012a). Mike_in_Ottawa responded with a transversal shift: he recognized and named their shared settler identity boundary and moved the conversation towards empathy and coalition-building:

Nellie, I have an issue with your statement "I demand respect because that's what I have been promised when I came here.” My family were immigrants to this country as well. They didn't demand respect and Italians were looked down upon for years in this country. We earned respect through hard work and becoming Canadian.... Be patient and the respect and understanding will come. (2012)

In response, Nellie_Niqabi's tone becomes more conversational. She thanks Mike_in_Ottawa for being "understanding" and "open minded," and acknowledges that "respect won't come on demand" but she also continues to name her experience with Islamophobia as different from that of Mike's Italian-Canadian heritage. She writes that anti-veiling attitudes are not "the same thing as another race or another culture. ... For us, we have no reason not to have respect. We do contribute to society. Our face veils don't really make a difference. It isn't that the Niqab is new here [as Mike_in_Ottawa suggested]. It's a whole different thing." She hopes, in her final sen- tence directed at Mike, "that someday, people might look at Niqabi women as people, and not as symbols of oppression :)" (2012b). Nellie_Niqabi's change in tone from argument to discussion, and her smiley emoticon illustrates a shift towards negotiation and understanding.

Establishing a shared identity location also led to resolution in an argument on HuffPost: Janice_Rosen called for a Canadian nation-state that rejects its past racist practices, such as the internment of JapaneseCanadians during World War II, and which instead shows "[f]lexibility and understanding and a willingness to extend this understanding to cultural differences" (2012). In response, AlisonCarnie, who had initially posted " $[\mathrm{t}]$ his is Canada ... adapt or go home" (2012a), writes "I was wrong and you are right ... you explained it brilliantly." AlisonCarnie went on to disclose: "I dated a man in the 1970s in Toronto whose parents were born in Vancouver and were of Japanese descent ... they were in an internment camp during WWII ... not one of Canada's proudest moments" (2012b). AlisonCarnie's turn to her past experience, directly after an admittance of wrong-thinking, illustrates that her attitudinal shift was related to her own close personal relationship with someone who had experienced the negative effects of being treated as an outsider. One aspect of her identity (former girlfriend of Japanese Canadian man) allowed her to find a common link and move to empathy and transformation.

Adding to Kristeva's theories about shared outsider status, a number of theorists suggest that building interpersonal connections can move people to better understand others' experiences, part of the rooting process in transversal politics. In her exploration of the tensions between white and racialized women's coalition building, María Lugones (1983) notes:

[T] he only motive that makes sense to me for your [privileged women] joining us ... is the motive of friendship. ... I see the "out of friendship" as the only sensical motivation for this ... because the task at hand for you is one of extraordinary difficulty. ... I do not think 
that you have any obligation to understand us. You do not have an obligation to abandon your imperialism, your universal claims, you reduction of us to your selves. (576)

Both Lugones and Elizabeth Spelman, with whom she writes, articulate the importance of dialogue that undoes insider/outsider binaries:

At first sight it may appear that the insider/outsider distinction disappears in the dialogue, but it is important to notice that all that happens is that we are now both outsider and insider with respect to each other. The dialogue puts us both in position to give a better account of each other's and our own experience. $(1983,577)$

Self-interest or a sense of obligation does not engage members of a dominant group in others' struggles long-term. Personal connection, "the motive of friendship," is "both the only appropriate and understandable motive for" the dominant group, they argue: "[Y] ou may be moved by friendship to undergo the very difficult task of understanding the text of our cultures by understanding our lives.... This learning calls for circumspection, for questioning of yourselves and your roles in your own culture" $(1983,581)$, which is the process of rooting, and of recognizing the many ways that we, individually, might define ourselves.

Although identity-markers are often cited in feminist intersectional scholarship as race, gender, class, ability, age, etc., they can and do encompass a number of ways that individuals identify themselves, including more mundane connections such as links to popular culture. One such example in our dataset illustrated that, in rooting, there are many ways to make connections and shift. When Liz_Wilson_2 wondered "what is more important in this situation, to prosecute the men that have assaulted her-giving justice and access to legal recourse for Islamic women in Canada or to force her to appear unveiled" (2012a), Gerry K. initially responded:

If they allow this then it sets a precedent. Should we let religious beliefs push back Cana- dian law? What's next ... Jedi was recently accredited as a recognized religion, what if they say they can't testify without light sabres on the stand, or their Yoda puppets? Where is the line drawn? (2012a)

Instead of a counter-attack, Liz_Wilson_2 writes: "How did you know I had a light saber and a puppet :o)" (2012b). She then again shares her concern "that this is also a way of intimidating this particular woman and could result in her choosing not to testify or to be so uncomfortable that her testimony is affected" (2012b). Commenter Dipl added in response to Gerry K.: "[I]f Yoda you wish on your legal team, sit he must at the counsel table" (2012), mimicking Yoda's speech syntax. The identity marker shared by these commenters is that of Star Wars fan: all three commenters know enough about the Star Wars franchise, and its relation to cultural movements like the Jedi religion in the UK, to make playful gestures towards it. Rooting out this shared identity marker produced a shift in Gerry K.'s tone and view: "I agree, and I really hope this is not an intimidation tactic" (2012b). This example points to the fluidity YuvalDavis argues is required when rooting to find a shared point of contact with those positioned in opposition. If rooting produces identity considerations that are embedded only in Black/White, straight/gay, man/woman, young/old, etc., then it is still simply "recognizing the self via the relationship with the significant Other," whereas "the whole point of transversal politics is to transcend the binary divisions of those who are in different positionings in the dialogue" (Yuval-Davis 2006, 284). The Jedi-based humour used by the Star Wars fans in this particular example illustrates that rooting and shifting can be playfully serious work.

The work of Kristeva, Spelman and Lugones, Ahmed, and transversal feminism moves away from the identity-based essentialism that leads to political infighting and towards adopting dialogic standpoint bridge building between groups and individuals. This work explains why the transformations that happened during the online discussions in our dataset are examples 
of transversal praxis in practice and effect, if not intent. Transversal feminist theorists have heralded the efficacy of "dialogic" consciousness-raising and antioppressive work "as a means of creating differenceand diversity-sensitive feminist solidarity across national and regional borders" (Lykke 2004, 75; see also Stoetzler and Yuval-Davis 2002, 315-35; Yuval-Davis 1997; Yuval-Davis and Stoetzler 2002). That work was apparent in our dataset when some commenters made connections between their own lives and the lives of others, whether those connections were made consciously or not.

\section{Conclusion: Postmodern and Transversal Theory and Conflict Resolution}

Feminist praxis is conceived of as a deliberate process, both in research and in personal development (see Hesse-Biber 2012). Sumi Cho, Kimberlé Crenshaw, and Leslie McCall, for example, outline three approaches to achieve intersectional feminist praxis. Elizabeth Evans notes that making the "transition from theory to practice" is a process of "application" (2016, 68). Elizabeth Sharp et al. (2017) recount how their work translates "scholarship to action" (76) because they were intentionally "guided by feminist praxis" to move from "frustration and anger into action" (80). Similarly, Katherine Allen (2000), and Lee Ann De Reus, April Few, and Libby Balter Blume (2005) note that praxis is the process of putting theory into action. Nancy Naples, in her reflections on the transformation of political theory into everyday politics, notes that "feminist praxis incorporates a commitment to self-reflexivity" that is necessary to transform experience into knowledge (2013, 659661). While feminist praxis does rely on reflexive and conscious transformation, which could explain why, given the tenacity of identity politics, Hill Collins (2017) noted that transversal feminist praxis is not yet met, we found evidence in our dataset that people can and do transform their everyday politics through the processes of rooting and shifting identified by transversal feminism, even if they are not consciously doing so.
These moments would not be possible without the permeability of postmodern identity positions. In her work, connecting Donna Haraway's postmodernism to transversal theory, Michelle Bastian points out that postmodern subjects are better able to reach points of empathy and respect than the fixed subject of modernity; that is, postmodern subjects are better able to engage in transversal praxis. Bastian draws attention to Haraway's argument that identity "is always constructed and stitched together imperfectly and therefore able to join with another, to see together without claiming the other" (qtd. in Bastian 2006, 1040). The everyday politics of identity work that took place when discussants recognized that their own identities were permeable and which allowed them to "join with another, to see together" diversely and move towards understanding, empathy, and resolution are examples of transversal praxis in action (also see Pryse 2000, 108-9). These transformations led discussants to "dismantl[e] the systems that maintain group antagonisms" (Bastian 2006, 1040), like the Islamophobia that was embedded in, and which surrounded, the $R$. v. N.S. decision. 


\section{References}

Ahmed, Sara. 2000. "Who Knows? Knowing Strangers and Strangeness." Australian Feminist Studies 13 (31): 49-68.

AlisonCarnie. December 20, 9:36 a.m., 2012 a. Comment. "Niqab Supreme Court Ruling,"

Huffington Post, http://www.huffingtonpost.ca/2012/12/20/niqabsupreme-court-ruling-canada_n_2335841.html.

. December 20, 1:28 p.m., 2012b. Comment. "Niqab Supreme Court Ruling," Huffington Post, http://www.huffingtonpost.ca/2012/12/20/niqabsupreme-court-ruling-canada_n_2335841.html.

Allahar, Anton. 1998. "Race and Racism: Strategies of Resistance." In Racism and Social Inequality in Canada: Concepts, Controversies and Strategies of Resistance, edited by Vic Satzewich, 335-354.

Toronto: Thompson Educational Publishing Inc.

Allen, Katherine. 2000. "A Conscious and Inclusive Family Studies." Journal of Marriage and the Family 62: 4-17.

Anonymous. December 20, 8:51 a.m., 2012. Comment. "Niqab Supreme Court Ruling," Huffington Post, http://www.huffingtonpost.ca/2012/12/20/niqabsupreme-court-ruling-canada_n_2335841.html.

Arat-Koc, Sedef. 2005. "The Disciplinary Boundaries of Canadian Identity after September 11: Civilizational Identities, Multiculturalism, and the Challenge of Anti-Imperialist Feminism." Social Justice Journal 32 (4): 32-49.

Archer Mann, Susan. 2012. Introduction to Doing Feminist Theory: From Modernity to Postmodernity, 129. New York: Oxford University Press.

ArtisteNow. December 20, 3:05 p.m., 2012. Comment. "Niqab Supreme Court Ruling,"
Huffington Post,

http://www.huffingtonpost.ca/2012/12/20/niqabsupreme-court-ruling-canada_n_2335841.html.

Awan, Imran. 2016. "Policing anti-Muslim hate crime on the Internet." In Islamophobia in Cyberspace, edited by Imran Awan, 137-150. London: Ashgate.

Bannerji, Himani. 2000. The Dark Side of the Nation: Essays on Multiculturalism, Nationalism, and Gender. Toronto: Canadian Scholars' Press Inc.

Bastian, Michelle. 2006. "Haraway's Lost Cyborg and the Possibilities of Transversalism." Signs 31 (4): 1027-1049.

Bhabha, Homi. 1994. The Location of Culture. New York: Routledge.

Bohaker, Heidi, and Franca Iacovetta. 2009.

"Making Aboriginal People 'Immigrants Too': A Comparison of Citizenship Programs for Newcomers and Indigenous Peoples in Postwar Canada, 1940s-1960s." The Canadian Historical Review 90 (3): 427-461.

Brian 25. December 20, 2012. Comment. "Niqab Ruling Opens the Door for Ottawa to Act," National Post, https://nationalpost.com/opinion/barbara-kayniqab-ruling-opens-the-door-for-ottawa-to-act

Butler, Judith. 1993. Bodies that Matter: On the Discursive Limits of 'Sex.' New York: Routledge.

Cammaerts, Bart. 2009. "Radical Pluralism and Free Speech in Online Public Spaces: The Case of North Belgian Extreme Right Discourses." International Journal of Cultural Studies 12 (6): 555-575.

Canadian Charter of Rights and Freedoms, 1982

Constitution Act, https://laws-

lois.justice.gc.ca/eng/const/page-15.html

Carr, James. 2016. Experiences of Islamophobia: 
Living with Racism in the Neoliberal Era. New York: Routledge.

Caton, Lou. 1997. Reading American Novels and Multicultural Aesthetics: Romancing the Postmodern Novel. New York: Palgrave MacMillan.

Chambers, Lori, and Jen Roth. 2014. "Prejudice Unveiled: The Niqab in Court." Canadian Journal of Law and Society / Revue Canadienne Droit et Société 29 (3): 381-395.

Cho, Sumi, Kimberlé Crenshaw, and Leslie McCall. 2013. "Toward a Field of Intersectionality Studies: Theory, Applications, and Praxis." Signs 38 (4): 785810.

Cindy V. December 20, 5:13 p.m., 2012. Comment. "Niqab Supreme Court Ruling," Huffington Post, http://www.huffingtonpost.ca/2012/12/20/niqabsupreme-court-ruling-canada_n_2335841.html.

Cockburn, Cynthia. 1998. The Spaces Between Us: Negotiating Gender and National Identities in Conflict. London: Zed Books.

De Reus, Lee Ann, April Few, and Libby Balter Blume. 2005. "Multicultural and Critical Race Feminisms: Theorizing Families in the Third Wave." In Sourcebook of Family Theory and Research, edited by Vern Bengtson, et. al., 447-468. Los Angeles: SAGE.

Dipl. December 20, 10:50 a.m., 2012. Comment. "Niqab Supreme Court Ruling," Huffington Post, http://www.huffingtonpost.ca/2012/12/20/niqabsupreme-court-ruling-canada_n_2335841.html.

Driedger, Leo. 1989. The Ethnic Factor: Identity in Diversity. Toronto: McGraw-Hill Ryerson.

Evans, Elizabeth. 2016. "Intersectionality as Feminist Praxis in the UK." Women's Studies International Forum 59: 67-75.

Gerry K. December 20, 8:57 a.m., 2012a. Comment.
"Niqab Supreme Court Ruling," Huffington Post, http://www.huffingtonpost.ca/2012/12/20/niqabsupreme-court-ruling-canada_n_2335841.html.

December 20, 9:13 a.m., 2012b. Comment. "Niqab Supreme Court Ruling," Huffington Post, http://www.huffingtonpost.ca/2012/12/20/niqabsupreme-court-ruling-canada_n_2335841.html.

Harding, Sandra. 1991. Whose Science, Whose Knowledge? London: Open University Press.

Haque, Eve. 2010. "Homegrown, Muslim and Other: Tolerance, Secularism, and the Limits of Multiculturalism." Social Identities 16 (1): 79-101.

Hesse-Biber, Sharlene, ed. 2012. Handbook of Feminist Research: Theory and Praxis. 2nd ed. Los Angeles: SAGE.

Hill Collins, Patricia. 1998. "Toward a New Vision: Race, Class, and Gender as Categories of Analysis and Connection.” Race, Sex \& Class 1 (1): 25-45.

Hill Collins, Patricia. 2017. "On Violence, Intersectionality, and Transversal Politics." Ethnic and Racial Studies 40(9): 1460-1473.

hooks, bell. 1989. "Travelling Theories: Travelling Theorists.” Inscriptions 5: 159-164.

James, Carl. 2005. "Perspectives on Multiculturalism in Canada." In Possibilities and Limitations: Multicultural Policies and Programs in Canada, edited by Carl James, 12-20. Winnipeg: Fernwood Publishing.

Janice_Rosen. December 20, 1:28 p.m., 2012. Comment. "Niqab Supreme Court Ruling," Huffington Post, http://www.huffingtonpost.ca/2012/12/20/niqabsupreme-court-ruling-canada_n_2335841.html.

Jiwani, Yasmin. 2006. Discourses of Denial: Mediations on Race, Gender and Violence. Vancouver: 
University of British Columbia Press.

Kahn, Richard and Douglas Kellner. 2004. "New Media and Internet Activism: From the 'Battle of Seattle' to Blogging." New Media and Society 6 (1): $87-95$.

Kamboureli, Smaro. 2007. Making a Difference: Canadian Multicultural Literatures in English, 2nd ed. Toronto: OUP.

Kanji, Samira and Azeezah Kanji. December 27, 2012. "In Defence of the Niqab," National Post https://nationalpost.com/opinion/samira-kanjiazeezah-kanji-in-defence-of-the-niqab .

Khan, Shahnaz. 1998. "Muslim Women:

Negotiations in the Third Space." Signs 23 (2): 463494.

Kolmar, Wendy and Frances Bartkowski. 2010. Feminist Theory, 3rd ed. New York: McGraw Hill.

Kristeva, Julia., 1991. Strangers to Ourselves, translated by Leon Roudiez. New York: University of Columbia Press.

LEAF, 2013. "Media Advisory and Backgrounder LEAF to Intervene in Ontario Court of Appeal Case - Women have Right to Wear Niqab in Court." CNW Group Ltd., https://www.newswire.ca/newsreleases/media-advisory-and-backgrounder---leaf-tointervene-in-ontario-court-ofappeal-case---womenhave-right-to-wear-niqab-in-court-544202352.html.

Liz_Wilson_2. December 20, 7:56 a.m., 2012a. Comment. "Niqab Supreme Court Ruling," Huffington Post, http://www.huffingtonpost.ca/2012/12/20/niqabsupreme-court-ruling-canada_n_2335841.html.

December 20, 8:42 a.m., 2012b. Comment. "Niqab Supreme Court Ruling," Huffington Post, http://www.huffingtonpost.ca/2012/12/20/niqabsupreme-court-ruling-canada_n_2335841.html.
Lorber, Judith. 2012. Gender Inequality: Feminist Theories and Politics, 5th ed. New York: Oxford University Press.

Lorde, Audre. 1984. "Age, Race, Class, and Sex: Women Redefining Difference." In Sister Outsider: Essays and Speeches, edited by Audre Lorde, 114-123. Freedom, CA: Crossing Press.

Love, Erik. 2017. Islamophobia and Racism in America, New York: NYU Press.

Lugones, Maria and Elizabeth Spelman. 1983. "Have We Got a Theory for You! Feminist Theory, Cultural Imperialism and the Demand for 'The Woman's Voice." Women's Studies International Forum 6 (6): 573-81.

Lykke, Nina. 2004. "Between Particularism, Universalism and Transversalism. Reflections on the Politics of Location of European Feminist Research and Education.” NORA 2 (12): 72-82.

McClintock, Anne. 1995. Imperial Leather: Race, Gender, and Sexuality in the Colonial Contest. London and New York: Routledge.

McDonough, Sheila. 2003. "Perception of the Hijab in Canada." In The Muslim Veil in North America: Issues and Debates, edited by Homa Hoodfar, Sheila McDonough, and Sajida Alvi, 121-143. Toronto: Women's Press.

Mike_in_Ottawa, December 24, 1:19 p.m., 2012, comment on "Niqab Supreme Court Ruling," Huffington Post, http://www.huffingtonpost.ca/2012/12/20/niqabsupreme-court-ruling-canada_n_2335841.html.

Mike T. December 20, 10:37 a.m., 2012a. Comment. "Niqab Supreme Court Ruling," Huffington Post, http://www.huffingtonpost.ca/2012/12/20/niqabsupreme-court-ruling-canada_n_2335841.html. 
December 20, 10:43 a.m., 2012b. Comment. "Niqab Supreme Court Ruling," Huffington Post, http://www.huffingtonpost.ca/2012/12/20/niqabsupreme-court-ruling-canada_n_2335841.html.

December 20, 2:52 p.m., 2012c. Comment. "Niqab Supreme Court Ruling," Huffington Post, http://www.huffingtonpost.ca/2012/12/20/niqabsupreme-court-ruling-canada_n_2335841.html.

Moghadam, Velentine, ed. 1994. Identity Politics and Women: Cultural Reassertions and Feminisms in International Perspective. Boulder: Westview Press.

Mohanty, Satya. 1997. Literary Theory and the Claims of History: Postmodernism, Objectivity, Multicultural Politics. Ithaca: Cornell UP.

Naples. Nancy. 2013. "Sustaining Democracy: Localization, Globalization, and Feminist Praxis." Sociological Forum 28 (4): 657-681.

Nellie_Niqabi, December 24, 11:01 a.m., 2012a, comment on "Niqab Supreme Court Ruling," Huffington Post, http://www.huffingtonpost.ca/2012/12/20/niqabsupreme-court-ruling-canada_n_2335841.html.

. December 26, 2:15 p.m., 2012b. Comment. "Niqab Supreme Court Ruling," Huffington Post, http://www.huffingtonpost.ca/2012/12/20/niqabsupreme-court-ruling-canada_n_2335841.html.

. January 11, 11:36 a.m., 2013. Comment. "Niqab Supreme Court Ruling," Huffington Post, http://www.huffingtonpost.ca/2012/12/20/niqabsupreme-court-ruling-canada_n_2335841.html.

Nicholas T, December 20, 11:01 a.m., 2012, comment on "Niqab Supreme Court Ruling," Huffington Post, http://www.huffingtonpost.ca/2012/12/20/niqabsupreme-court-ruling-canada_n_2335841.html.

novabird, December 20, 10:02 a.m., 2012, comment on "Niqab Supreme Court Ruling," Huffington Post, http://www.huffingtonpost.ca/2012/12/20/niqabsupreme-court-ruling-canada_n_2335841.html.

Overt Enigma. December 20, 10:02 a.m., 2012a. Comment. "Niqab Supreme Court Ruling," Huffington Post, http://www.huffingtonpost.ca/2012/12/20/niqabsupreme-court-ruling-canada_n_2335841.html.

December 20, 10:12 a.m., 2012b. Comment. "Niqab Supreme Court Ruling," Huffington Post, http://www.huffingtonpost.ca/2012/12/20/niqabsupreme-court-ruling-canada_n_2335841.html.

Perry, Barbara. 2014. "Gendered Islamophobia: Hate Crime Against Muslim Women.” Social Identities 20 (1): 74-89.

Poster, Mark. 2009. "Postmodernity and the Politics of Multiculturalism: The Lyotard-Habermas Debate over Social Theory." Modern Fiction Studies 38 (3): 567-80.

Pryse, Marjorie. 2000. "Trans/Feminist Methodology: Bridges to Interdisciplinary Thinking." NWSA Journal 12 (2): 105-188.

R. v. N.S., [2012], 3 SCR 726.

RK2880, December 20, 10:20 a.m., 2012, comment on "Niqab Supreme Court Ruling," Huffington Post, http://www.huffingtonpost.ca/2012/12/20/niqabsupreme-court-ruling-canada_n_2335841.html.

rattler, December 20, 2012, comment on Barbara Kay, "Niqab Ruling Opens the Door for Ottawa to Act," National Post,

http:/fullcomment.nationalpost.com/2012/12/20/ba rbara-kay-niqab-ruling-opens-the-door-for-ottawa-toact/.

Razack, Sherene. 2008. Casting Out: The Eviction of Muslims from Western Law and Politics. Toronto: University of Toronto Press. 
Sharp, Elizabeth et al. 2017. "From Furious to Fearless: Faculty Action and Feminist Praxis in Response to Rape Culture on College Campuses." Family Relations: Interdisciplinary Journal of Applied Family Studies 66: 75-88.

Simpson, Jennifer, Carl James, and Johnny Mack. 2011. "Multiculturalism, Colonialism, and Racialization: Conceptual Starting Points." Review of Education, Pedagogy, and Cultural Studies 33: 285305.

Stoetzler, Marcel and Nira Yuval-Davis. 2002. "Standpoint Theory, Situated Knowledge and the Situated Imagination." Feminist Theory 3 (3): 315-35.

Torontosaurous, December 20, 8:27 a.m., 2012a, comment on "Niqab Supreme Court Ruling," Huffington Post, http://www.huffingtonpost.ca/2012/12/20/niqabsupreme-court-ruling-canada_n_2335841.html.

Vidal, Ava. May 6, 2014. “'People grab our veils, call us terrorists and want us dead': What it's really like to be a Muslim woman in Britain," The Telegraph, http://www.telegraph.co.uk/women/womenspolitics/10804880/Islamophobia-People-grab-ourveils-call-us-terrorists-and-want-us-dead-What-itsreally-like-to-be-a-Muslim-woman-in-Britain.html.

Yanyu, Zeng. 2004. Towards Postmodern Multiculturalism: A New Trend of African American and Jewish American Literature Viewed through Ishmael Reed and Philip Roth. Xiamen, China: Xiamen UP.

Yasmin, December 20, 2012, comment on Barbara Kay, "Niqab Ruling Opens the Door for Ottawa to Act," National Post, https://nationalpost.com/opinion/barbara-kay-niqabruling-opens-the-door-for-ottawa-to-act.

Yuval-Davis, Nira. 1994. "Women, Ethnicity and Empowerment." In Shifting Identities Shifting Racisms: A Feminism and Psychology Reader, edited by KumKum Bhavnani and Ann Phoenix, 179-97. London: SAGE.
1997. Gender \& Nation. London, SAGE.

2006. "Human/Women's Rights and Feminist Transversal Politics." In Global Feminism:

Transnational Women's Activism, Organizing, and Human Rights, edited by Myra Marx Ferree, and Aili Mari Tripp, 275-295. New York: NYU Press.

Yuval-Davis, Nira and Marcel Stoetzler. 2002. "Imagined Boundaries and Borders: A Gendered Gaze." The European Journal of Women's Studies 9(3): 329-45.

Zheng, Cindy. December 20, 1:49 a.m., 2012, comment on "Supreme Court in Split Decision Rules Niqab OK in Court in Some Cases," Macleans http://www.macleans.ca/general/supreme-court-insplit-decision-rules-niqab-ok-in-court-in-some-cases/. 